\title{
Uji Resistensi Bakteri terhadap Arsen yang di Isolasi dari Sedimen di Muara Sungai Totok
}

\author{
${ }^{1}$ Tessalonicha J. Rompis \\ ${ }^{2}$ Widdhi Bodhi \\ ${ }^{2}$ Fona Budiarso
}

\author{
${ }^{1}$ Program Studi Pendidikan Dokter Fakultas Kedokteran Universitas Sam Ratulangi Manado \\ ${ }^{2}$ Bagian Kimia Fakultas Kedokteran Universitas Sam Ratulangi Manado \\ Email: Tessajoanella@gmail.com
}

\begin{abstract}
Arsenic is still used in lots of human activities that results in environmental pollution. Arsenic is also found in nature in a small quantity. Gold mining industry is one of the human activities that uses arsenic. Mining waste that is not managed properly can inflict environmental pollution and harms the human health due to its toxic-substance content. This study was aimed to isolate and identify bacteria in the soil sediment obtained from the estuary area of Totok River, Southeast Minahasa and tested the bacteria's resistance levels to arsenic. Bacteria were isolated from sediment samples from the estuary area of Totok River, and the isolated bacteria were grown in agar media containing arsenic trioxide. Bacteria identification were perfomed by using morphological, physiological and biochemical tests. The results showed that bacteria grew successfully in 10 isolates; 2 isolates were Gram negative bacteria and 8 isolates were Gram positives bacteria. All isolates showed no motility. Identification of bacteria revealed four genera: Bacillus sp., Streptococcus sp., Acetobacter sp, and Escherichia $s p$ that were resistant to arsenic $1000 \mathrm{ppm}$. Conclusion: There were 4 genera of arsenicresistant bacteria identified in the sediment of the estuary area of Totok River, as follows: Bacillus sp., Streptococcus sp., Acetobacter sp, and Escherichia sp. All of them were resistant to arsenic $1000 \mathrm{ppm}$.
\end{abstract}

Keywords: sediment, arsenic-resistant bacteria

\begin{abstract}
Abstrak: Arsen (As) masih banyak ditemukan dalam kegiatan manusia yang berakibat pencemaran terhadap lingkungan. Arsen juga dapat ditemukan di alam secara alami namun dalam jumlah yang sedikit. Industri pertambangan emas merupakan salah satu kegiatan manusia yang menggunakan arsen. Limbah pertambangan yang tidak dikelola dengan baik dapat mencemari lingkungan dan mengganggu kesehatan manusia karena berpotensi mengandung racun yang berbahaya. Penelitian ini bertujuan untuk mengidentifikasi bakteri resisten arsen serta tingkat resistensinya yang terdapat pada sedimen di muara Sungai Totok Kecamatan Ratatotok Kabupaten Minahasa Tenggara Sulawesi Utara. Bakteri diisolasi dari sedimen di muara sungai Totok dan ditumbuhkan pada media agar yang mengandung arsen trioksida. Identifikasi dari bakteri yang tumbuh menggunakan uji fisiologi, uji morfologi dan uji biokimia. Hasil penelitian mendapatkan 10 isolat dengan bakteri yang berhasil tumbuh, yaitu 2 isolat bakteri Gram negatif dan 8 isolat bakteri Gram positif. Semua isolat tidak menunjukkan adanya motilitas dan dapat dikategorikan ke dalam empat kelompok genus yaitu Bacillus sp., Streptococcus sp., Acetobacter sp, dan Escherichia sp. Keempat genus bakteri ini resisten terhadap arsen hingga konsentrasi 1000 ppm. Simpulan: Terdapat empat genus bakteri resisten arsen yang teridentifikasi dalam sedimen di muara Sungai Totok, yaitu Bacillus sp., Streptococcus sp., Acetobacter sp, dan Escherichia sp. Kesemuanya resisten terhadap arsen hingga konsentrasi 1000 ppm.
\end{abstract}

Kata kunci: sedimen, bakteri resisten arsen 
Berkembangnya ilmu pengetahuan dan teknologi yang semakin cepat, dapat menguntungkan dan merugikan kehidupan manusia. Keuntungan yang didapatkan berupa fasilitas kehidupan yang lebih mudah dan serba instan, sedangkan kerugian yang didapatkan yaitu pencemaran lingkungan di udara, air, maupun tanah. ${ }^{1}$

Metaloid adalah elemen anorganik non logam yang memiliki karakter logam. Arsen (As) termasuk dalam kategori metaloid yang dapat ditemukan di air, tanah, bebatuan, udara dan semua yang hidup dalam jumlah yang sedikit. Bahan kimia ini bisa juga diperoleh sebagai hasil tambahan dari suatu industri pertambangan dan dari proses pemurnian logam perak. Selain penggunaan di bidang industri pertambangan, senyawa arsen juga dapat ditemukan pada industri pengelolahan biji logam, industri peptisida, industri pelapisan logam, dan proses penghilangan cat atau paint stripping. Masuknya arsen kedalam perairan juga dapat berasal dari limbah pertanian seperti pembuangan pestisida, insektisida, herbisida, algisida, rodentisida, dan pupuk. Secara alamiah arsen dapat masuk kedalam lingkungan melalui debu vulkanik yang dikeluarkan dari letusan-letusan gunung berapi, pelapukan bebatuan, dan mineralmineral yang mengandung arsen yang kemudian masuk kedalam air tanah., ${ }^{2,3}$

Di hulu Sungai Totok terdapat pertambangan rakyat yang mengelola hasil tambangnya menggunakan tromol. Pengelolaan ini menggunakan logam berat sebagai penangkap emas dari batuan yang digiling menjadi halus dalam tromol. Dampak penggunaan logam berat pada pertambangan masyarakat sangat memprihatinkan karena teknik pengolahan emas yang digunakan masih traditional sehingga limbah pertambangan yang tidak dikelola dengan baik dan berpotensi racun terlepas ke lingkungan cukup besar. Penelitian ini bertujuan untuk mengidentifikasi bakteri resisten arsen pada sedimen di muara sungai Totok. ${ }^{4}$

\section{METODE PENELITIAN}

Jenis penelitian ini ialah deskriptif eskploratif. Pengambilan sampel dilakukan di muara Sungai Totok Kecamatan Ratatotok Kabupaten Minahasa Tenggara Sulawesi Utara dan penelitian dilakukan di Laboratorium Farmasi Fakultas MIPA Universitas Sam Ratulangi.

Populasi penelitian ini ialah berbagai jenis bakteri yang terdapat pada sedimen di muara sungai Totok Kecamatan Ratatotok. Sampel penelitian yang digunakan ialah koloni bakteri yang resisten terhadap arsenik, yang terdapat pada sedimen.

Untuk identifikasi bakteri, pada tahap awal dilakukan uji resistensi bakteri terhadap arsen. Bakteri diisolasi dari sedimen di muara sungai Totok dan ditumbuhkan pada media agar yang mengandung arsen trioksida $\left(\mathrm{As}_{2} \mathrm{O}_{3}\right)$ dengan konsentrasi kontrol, 5 ppm, 10 ppm, 20 ppm, 40 ppm, 80 ppm, 100 ppm, 300 ppm, 500 ppm, dan $1000 \mathrm{ppm}$. Setelah itu dilakukan uji morfologi dan fisiologi terhadap koloni bakteri. Uji morfologi dilakukan dengan pewarnaan Gram, sedangkan uji fisiologi dilakukan untuk menentukan ada tidaknya pergerakan (motilitas) bakteri menggunakan media agar padat. Uji biokimia yang dilakukan meliputi uji fermentasi karbohidrat, uji indol, uji sitrat, uji $\mathrm{H}_{2} \mathrm{~S}$, uji katalase, dan uji lisin dekarboksilase.

\section{HASIL PENRLITIAN}

\section{Hasil Uji Resistensi Arsen, Uji Morfologi dan Fisiologi Bakteri}

Pada uji resistensi bakteri pada media agar terlihat 10 media agar yang mengandung arsen trioksida $\left(\mathrm{As}_{2} \mathrm{O}_{3}\right)$ mampu ditumbuhi bakteri. Hasil yang didapatkan pada uji morfologi dalam bentuk pewarnaan Gram. Isolat dengan label RM (Ratatotok Muara) 5 ppm ialah bakteri bentuk kokus Gram positif. Isolat dengan label RM 20 ppm ialah bakteri bentuk kokus Gram negatif. Isolat dengan label RM 40 ppm ialah bakteri bentuk basil Gram negatif. Isolat dengan label RM kontrol, RM 10 ppm, RM 80 ppm, RM 100 ppm, RM 300 ppm, RM 500 ppm, dan RM 1000 ppm merupakan bakteri bentuk basil Gram positif.

Pada uji fisiologi, hasil pengujian 10 
isolat pada media nutrient agar padat didapatkan 2 isolat positif dan 8 isolat negatif, yang dapat dilihat pada media nutrient agar padat terdapat pertumbuhan bakteri yang menyebar di sekitar tempat penusukan.

\section{Hasil Uji Biokimia dan Identifikasi Bakteri}

Uji fermentasi karbohidrat pada sampel dilakukan bersamaan dengan uji $\mathrm{H}_{2} \mathrm{~S}$. Uji ini dilakukan pada media Triple Sugar Iron (TSI) agar. Isolat dengan label RM 10 ppm tidak menunjukkan adanya perubahan warna sehingga media tetap berwarna merah. Hal ini menunjukkan bahwa tidak terjadi fermentasi karbohidrat apapun pada isolat. Isolat dengan label RM 5 ppm terjadi perubahan warna media, dari merah menjadi kuning sepenuhnya tanpa disertai pembentukan gas pada tabung. Hal ini menunjukkan adanya fermentasi karbohidrat secara keseluruhan tanpa disertai pembentukan gas $\left(\mathrm{CO}_{2}\right)$. Isolat dengan label RM 20 ppm memiliki perubahan menjadi warna kuning pada bagian dasar (butt) dan tetap merah pada bagian permukaan (slant) tanpa disertai pembentukan gas $\left(\mathrm{CO}_{2}\right)$. Hal ini berarti bahwa pada sampel hanya terjadi fermentasi glukosa saja tanpa disertai fermentasi laktosa dan sukrosa. Isolat dengan label RM $80 \mathrm{ppm}$, RM 100 ppm, RM 300 ppm, RM 500 ppm, dan RM 1000 ppm memiliki perubahan menjadi warna kuning pada bagian dasar dan tetap merah pada bagian permukaan dengan disertai pembentukan gas $\left(\mathrm{CO}_{2}\right)$. Hal ini berarti bahwa pada sampel hanya terjadi fermentasi glukosa saja tanpa disertai fermentasi laktosa dan sukrosa dengan disertai pembentukan gas $\left(\mathrm{CO}_{2}\right)$.

Pada uji $\mathrm{H}_{2} \mathrm{~S}$ digunakan media TSI agar dan hasil positif terdapat pada isolat dengan label RM kontrol dan RM 40 ppm, dimana pada media terlihat adanya perubahan menjadi warna hitam yang menandakan bahwa bakteri tersebut dapat membentuk $\mathrm{H}_{2} \mathrm{~S}$.
Pada uji indol menggunakan media nutrient agar padat yang diberi 5 tetes reagen Kovac's, kemudiam didiamkan sebentar. Pada uji indol tidak didapatkan hasil positif namun pada beberapa isolat terdapat gumpalan berwarna hijau yang mungkin akibat dari kontaminan.

Pada uji sitrat digunakan media Simmon's Citrate agar. Hampir semua isolat memberikan hasil positif dimana terjadi perubahan warna media dari hijau menjadi biru. Hasil negatif didapatkan pada isolat dengan label RM kontrol, RM 5 ppm, dan RM 10 ppm dimana tidak terjadi perubahan warna pada media.

Pada uji lisin dekarboksilase digunakan media Lysin Iron agar. Terdapat 3 isolat yang memberikan hasil positif, berupa adanya perubahan warna lembayung (keunguan). Hasil positif terdapat pada isolat dengan label RM 5ppm, RM 10ppm dan RM 40ppm namun pada satu isolat didapatkan media tampak lebih pekat yaitu RM 40 ppm. Hal ini menunjukkan bahwa bakteri dapat melakukan dekarboksilasi dalam asam amino berupa lisin melalui enzim dekarboksilase.

Pada uji katalase digunakan media nutrient broth yang ditetesi larutan hidrogen peroksida. Hasil positif ditunjukkan dengan munculnya busa/gas yang merambat cepat keluar dari tabung. Hampir semua isolat menunjukkan hasil positif, namun hanya satu isolat dengan label RM 5 ppm yang menunjukkan hasil negatif. Hal ini berarti bakteri pada isolat memiliki enzim katalase yang dapat memecah $\mathrm{H}_{2} \mathrm{O}_{2}$ menjadi $\mathrm{H}_{2} \mathrm{O}$ dan $\mathrm{O}_{2}$.

Identifikasi genus bakteri dilakukan dengan cara membandingkan uji yang didapat dalam penelitian dengan Bergey's Manual of Determinative Bacteriology. Hasil penelitian menunjukan bahwa terdapat 1 bakteri Streptococcus sp., 1 bakteri Acetobacter sp., 1 bakteri Escherichia sp., dan 7 bakteri Bacillus sp.

Hasil uji secara keseluruhan di rangkum dalam Tabel 1. 
Tabel 1. Hasil uji isolat bakteri resisten arsen dengan metode identifikasi bakteri

\begin{tabular}{|c|c|c|c|c|c|c|c|c|c|c|}
\hline \multirow[b]{2}{*}{$\begin{array}{c}\text { Uji } \\
\text { Identifikasi }\end{array}$} & \multicolumn{10}{|c|}{ Isolat Bakteri Resisten si Arsen } \\
\hline & $\begin{array}{c}\mathrm{RM} \\
\text { kontrol }\end{array}$ & RM 5 & $\begin{array}{c}\text { RM } \\
10\end{array}$ & RM20 & RM40 & RM80 & RM 100 & RM300 & RM500 & $\begin{array}{l}\mathrm{RM} \\
1000 \\
\end{array}$ \\
\hline Morfologi & $(+) \mathrm{B}$ & $(+) \mathrm{K}$ & $(+) \mathrm{B}$ & (-) $\mathrm{K}$ & $(-) \mathrm{B}$ & $(+) \mathrm{B}$ & (+) B & (+) B & (+) B & $(+) \mathrm{B}$ \\
\hline F.Karbohidrat & - & $\mathrm{g} / \mathrm{l} / \mathrm{s}$ & - & $\mathrm{g}$ & - & g(gas) & g(gas) & $\mathrm{g}(\mathrm{gas})$ & $\mathrm{g}(\mathrm{gas})$ & $\mathrm{g}$ (gas) \\
\hline Motil & + & - & - & - & - & + & - & - & - & - \\
\hline Indol & - & & - & - & - & - & - & - & - & - \\
\hline Sitrat & - & - & - & + & + & + & + & + & + & + \\
\hline Lysin & - & + & + & - & + & - & - & - & - & - \\
\hline $\mathrm{H}_{2} \mathrm{~S}$ & + & & - & - & + & - & - & - & - & - \\
\hline Katalase & + & - & + & + & + & + & + & + & + & + \\
\hline
\end{tabular}

RM: Ratatotok Muara; B: Basil; K: Kokus; g: glukosa; f: fruktosa; l: laktosa; gas: ada produksi gas dari hasil fermentasi karbohidrat

Tabel 2. Genus bakteri resisten arsen

\begin{tabular}{cc}
\hline Kode Isolat & Genus \\
\hline RM kontrol & Bacillus $s p$ \\
RM 5ppm & Streptococcus $s p$ \\
RM 10ppm & Bacillus $s p$ \\
RM 20 ppm & Acetobacter $s p$ \\
RM 40ppm & Escherichia $s p$ \\
RM 80ppm & Bacillus $s p$ \\
RM 100ppm & Bacillus $s p$ \\
RM 300ppm & Bacillus $s p$ \\
RM 500ppm & Bacillus $s p$ \\
RM 1000ppm & Bacillus $s p$ \\
\hline
\end{tabular}

\section{BAHASAN}

Bakteri merupakan mikroorganisme bersel tunggal dengan konfigurasi seluler prokariotik (tidak mempunyai selubung inti). Bakteri umumnya memiliki ukuran panjang 0,5-10 $\mu \mathrm{m}$ dan lebar 0,5-2,5 $\mu \mathrm{m}$. Struktur bakteri yang paling penting ialah dinding sel bakteri yang dapat digolongkan menjadi dua kolompok yaitu Gram positif dan Gram negatif. Berdasarkan bentuknya bakteri dibagi menjadi tiga yaitu kokus (berbentuk bulat seperti bola), basil (berbentuk batang), dan spiral (berbentuk lengkung). ${ }^{5,6}$

Pada media nutrient agar dengan isolat yang berkonsentrasi rendah ditemukan peningkatan pertumbuhan bakteri, sedangkan pada isolat yang berkonsentrasi tinggi ditemukan penurunan pertumbuhan bakteri. Bila koloni bakteri menetap pada kondisi yang menekan seperti konsentrasi arsen tinggi dalam waktu lama, hal ini dapat menyebabkan koloni bakteri tersebut mengembangkan mekanisme untuk mendetoksifikasi dan mengatasi pembatasan untuk bertumbuh sehingga walaupun pada konsentrasi tinggi arsen masih terdapat bakteri yang tumbuh. ${ }^{7,8}$ Mikroba mendapatkan proteksi melawan racun melalui formasi biofilm. Kemungkinan melalui formasi biofilm bakteri-bakteri yang telah diisolasi dapat melawan racun pada arsen. ${ }^{9}$

Bacillus sp. merupakan genus bakteri basil Gram positif aerob yang muncul dalam bentuk rantai, dan berukuran 0,5-2,5 $\mathrm{x} 1,2-10 \mu \mathrm{m}$. Sebagian besar anggota genus ini ialah organisme saprofit, sering dijumpai pada tanah, air dan udara, serta pada vegetasi. Bakteri genus ini juga tumbuh dalam makanan dan menghasilkan entero- 
toksin atau toksin emetik yang menimbulkan sindrom muntah, muncul 1-6 jam setelah makan. Uji katalase positif didapatkan pada sebagian besar spesies. ${ }^{10}$

Streptococcus sp. ialah bakteri berbentuk sferis, kokus Gram positif yang biasanya berbentuk rantai atau berpasangan ketika tumbuh pada media larutan. Bakteri pada genus ini dapat bertahan hingga suhu $37^{\circ} \mathrm{C}$ dengan suhu pertumbuhan terbatas $45^{\circ} \mathrm{C}$. Pada uji fisiologi, bakteri ini non motil. Pada uji fermentasi karbohidrat, karbohidrat dapat terfermentasi namun gas $\mathrm{CO}_{2}$ terbentuk dalam jumlah yang sangat kecil atau tidak sama sekali. Beberapa streptococcus sp. merupakan flora normal, namun sebagian lainnya berkaitan dengan penyakit serius. ${ }^{10,11}$

Acetobacter sp. merupakan bakteri berbentuk sferis, kokus gram negatif, biasanya sendiri, berpasangan maupun berantai. Selnya motil atau tidak motil, membentuk koloni-koloni pucat. Sebagian strain tidak memroduksi pigmen. Sebagian kecil strain memroduksi pigmen yang dapat larut di air atau koloni berwarna merah muda dikarenakan porphyrin. Bakteri genus ini dapat bertahan hingga suhu $25-30^{\circ} \mathrm{C}$ dengan $\mathrm{pH}$ optimum pertumbuhan ialah 5,4-6,3. ${ }^{10}$

Escherichia sp. merupakan bakteri anaerob fakultatif, berbentuk basil yang berpasangan maupun sendiri, Gram negatif, serta dapat bersifat motil maupun nonmotil. Kapsul atau mikro kapsul dapat terlihat di strain. Uji fermentasi karbohidrat menunjukkan adanya asam dan gas, tetapi ada juga yang tidak. Dapat ditemukan pada feses, namun kadang-kadang bersifat patologik. Salah satu spesies Escherichia yang dapat menimbulkan penyakit ialah $E$. coli. Bakteri jenis ini menjadi patogen jika jumlahnya dalam saluran cerna meningkat atau berada diluar usus. E. coli menghasilkan enterotoksin yang dapat menyebabkan diare. Penyakit yang disebabkan oleh bakteri ini yaitu infeksi saluran kemih, diare, sepsis, dan meningitis. ${ }^{10,12}$

\section{SIMPULAN}

Berdasarkan hasil penelitian ini dapat disimpulkan bahwa terdapat bakteri resis- ten arsen pada sedimen yang diambil dari muara sungai Totok Kecamatan Ratatotok. Genus yang diidentifikasi berdasarkan uji morfologi, uji fisiologi, dan uji biokimia ialah Bacillus sp., Streptococcus sp., Acetobacter sp, dan Escherichia sp.

\section{DAFTAR PUSTAKA}

1. Sembel DT. Toksikologi Lingkungan. Yogyakarta: Andi Offset, 2015.

2. Patel PC, GoulhenF, Boothman C, Gault AG, Charnock JM, Kalia K, et al. Arsenate detoxification in a Pseudomonad hypertolerant to arsenic. Arch Microbiol . 2007;187:171- 83.

3. Lasut HE, Kawung NJ, Lasut MT. Kandungan arsen berbentuk suspensi dan terarut, di perairan teluk Manado. Jurnal Pesisir dan Laut Tropis. 2016;1(1):30-8.

4. Rumampuk NDC, Warouw V. Bioakumulasi total merkuri, arsen, kromium, cadmium, timbal di Teluk Totok dan Teluk Buyat, Sulawesi Utara. Jurnal LPPM Bidang Sains dan Teknologi. 2015; 2(2):49-59.

5. Prasetyo TUW. Pola resistennsi bakteri dalam darah terhadap Kloramfenikol, Trimethoprim/Sulfametoksazol, dan Tetrasiklin di Laboratorium Mikrobiologi Klinik Fakultas Kedokteran Universitas Indonesia (LMK FKUI) pada tahun 2001-2006 [Skripsi]. Jakarta: Fakultas Kedokteran Universitas Indonesia; 2009.

6. Zarkasyi H. Biopsorsi logam merkuri $(\mathrm{Hg})$ oleh Bacillus megaterium asal hilir sungai Cisadane [Skripsi]. Jakarta: Universitas Islam Negeri Syarif Hidayatullah; 2008.

7. Huang A, Teplitski M, Rathinasabapathi B, Ma L. Characterization of arsenicresistant bacteria from the rhizosphere of arsenic hyperaccumulator Pteris vittata. Can J Microbiol. 2010;56:23646.

8. Silver S, Phung LT. Genes and enzymes involved in bacterial oxidation and reduction of inorganic arsenic. Appl Environ Microbiol. 2005;71:599-608.

9. Mah TFC, O'Toole GA. Mechanisms of biofilm resistance to antimicrobial agents. Trends Microbiol. 2001;9:34-9.

10. John GH, Noel RK, Peter HAS, James TS, Stanley TW. Bergey's Manual of 
134 Jurnal e-Biomedik (eBm), Volume 6, Nomor 2, Juli-Desember 2018

Determinative Bacteriology (9th ed). Baltimore: The Williams \& Wilkins Company, 1994.

11. Brooks GF, Carrol KC, Butel JS, Morse SA, Mietzner TA. Jawetz, Melnick, \& Adelberg's Medical Microbiology. In:
Adityaputri A, editor. Jawetz, Melnick, \& Adelberg Mikrobiologi Kedokteran (25th ed). Jakarta: EGC, 2010.

12. Kusuma SAF. Escherichia coli. Jatinangor: Fakultas Farmasi Universitas Padjadjaran; 2010. 